\title{
Intravenous administration of Penicillin results in therapeutic intravitreal levels in chronic postoperative endophthalmitis
}

\author{
Chloe Thabet ${ }^{1}$, Chloe C. C. Gottlieb ${ }^{1,2,3}$, Bernard R. Hurley ${ }^{1,2,3}$, Guijun Zhang ${ }^{3}$, Adeel Sherazi ${ }^{4}$ and \\ Jonathan B. Angel ${ }^{1,3,4^{*}}$ (D)
}

\begin{abstract}
Importance: The role of systemic antibiotics in the treatment of bacterial endophthalmitis remains controversial. While penicillin is a highly effective antibiotic against bacteria that frequently cause endophthalmitis, the ability of systemically administered Penicillin $\mathrm{G}$ to penetrate into the vitreous at adequate therapeutic concentrations has not been studied. Its role in the treatment of endophthalmitis, particularly for bacteria for which it is the antibiotic of choice, therefore remains unknown.

Objective: We sought to determine whether intravenous administration of Penicillin G leads to adequate therapeutic concentrations in the vitreous for the treatment of bacterial endophthalmitis.

Design and setting: This study was conducted in an ambulatory setting, at the Ottawa Hospital Eye Institute, a university-affiliated tertiary care center, where a 77-year old gentleman with chronic post-cataract surgery Actinomyces neuii endophathalmitis was treated with intravenous Penicillin $\mathrm{G}\left(4 \times 10^{6}\right.$ units every $\left.4 \mathrm{~h}\right)$ and intravitreal ampicillin $(5000 \mu \mathrm{g} / 0.1 \mathrm{~m} 1)$.
\end{abstract}

Main outcomes and measures: Intravitreal concentration of Penicillin $\mathrm{G}$ and ampicillin were obtained at the time of intraocular lens removal, measured by high-performance liquid chromatography.

Results: The intravitreal concentration of penicillin and ampicillin was $3.5 \mu \mathrm{g} / \mathrm{ml}$ and $0.3 \mu \mathrm{g} / \mathrm{ml}$, respectively. Both the concentration of penicillin and ampicillin were within the level of detection of their respective assays (penicillin $0.06-5 \mu \mathrm{g} / \mathrm{ml}$, ampicillin $0.12-2.5 \mu \mathrm{g} / \mathrm{ml})$.

Conclusion and relevance: This study shows that intravenous Penicillin $G$ administered every four-hours allows for adequate intravitreal concentrations of penicillin. Future studies are required to determine if the results of this study translate into improved clinical outcomes.

\section{Introduction}

Postoperative bacterial endophthalmitis is an uncommon, but very serious, complication of intraocular surgery [1]. Empiric antibiotic regimens commonly include intravitreal injections of vancomycin and ceftazidime for broad-spectrum coverage of Gram-positive and Gram-

\footnotetext{
*Correspondence: jangel@ohri.ca

${ }^{1}$ Faculty of Medicine, University of Ottawa, Ottawa, ON, Canada

${ }^{3}$ Ottawa Hospital Research Institute, Ottawa, ON, Canada

Full list of author information is available at the end of the article
}

negative organisms [1]; however, no well supported treatment guidelines exist for the management of nonendogenous bacterial endophthalmitis [2]. The role of systemic antibiotics remains controversial [2].

The foundation of post-cataract surgery endophthalmitis management is based on the Endophthalmitis Vitrectomy Study (EVS), conducted over 25 years ago and which aimed to determine the role of intravenous antibiotics in the management of acute post-operative bacterial endophthalmitis [3]. In this study, the addition

\section{Springer Open}

() The Author(s). 2021 Open Access This article is licensed under a Creative Commons Attribution 4.0 International License, which permits use, sharing, adaptation, distribution and reproduction in any medium or format, as long as you give appropriate credit to the original author(s) and the source, provide a link to the Creative Commons licence, and indicate if changes were made. The images or other third party material in this article are included in the article's Creative Commons licence, unless indicated otherwise in a credit line to the material. If material is not included in the article's Creative Commons licence and your intended use is not permitted by statutory regulation or exceeds the permitted use, you will need to obtain permission directly from the copyright holder. To view a copy of this licence, visit http://creativecommons.org/licenses/by/4.0/. 
of intravenous to intravitreal antibiotics provided no benefit in visual acuity or media clarity [3]. Generalizability of these results, however, poses several challenges. First, patients with chronic or severe endophthalmitis were excluded from study. Second, the systemic antibiotics used (ceftazidime and amikacin) have poor activity against common Gram-positive organisms seen in endophthalmitis, with poor penetration into the vitreous (specifically amikacin). Third, the duration of systemic antibiotics (510 days), might have been too short to confer any benefit [2]. Since publication of the EVS, there has been little new literature to guide systemic antibiotics for the management of endophthalmitis [2].

Penetration of systemically administered antimicrobials into the intraocular space, through the bloodretinal barrier (BRB) is limited by the retinal pigment epithelium (RPE) and the tight junctions of retinal capillaries. Diffusion of antibiotics into the vitreous is restricted by poor vascularization and a small diffusion surface. Consequently, lower drug concentrations occur in the vitreous compared to the plasma [4]. Bypassing the $\mathrm{BRB}$ via intravitreal administration has traditionally been preferred and is the mainstay of treatment for bacterial endophthalmitis. Data derived from studies in humans suggest that carbapenems, linezolid, daptomycin, and high-dose moxifloxacin achieve adequate intraocular levels when administered intravenously [2]. Studies in rabbits also suggest that systemic administration of imipenem, ciprofloxacin, cefazolin, ceftazidime and vancomycin achieve adequate levels in the eye but extrapolation of this information to humans must be done with caution [5].

Penicillin is a highly effective antimicrobial against the predominant organisms seen in bacterial endophthalmitis and is the drug of choice for most streptococci and many anaerobic bacteria. However, the intravitreal penetration of systemically administered penicillin has not been studied. Based on similar properties between the blood-brain-barrier and the $\mathrm{BRB}$, it is presumed that penetration of intravenous penicillin into the vitreous space is minimal [2]. To our knowledge, we are the first to report intravitreal levels of penicillin following systemic administration of Penicillin G in a patient with chronic postoperative Actinomyces neuii endophthalmitis.

\section{Methods}

Analyses of intravitreal levels of penicillin and ampicillin in a patient with chronic post-cataract surgery endophthalmitis caused by Actinomyces neuii and requiring vitrectomy with lens removal were performed. A total of two intravitreal doses of ampicillin were given one-week apart. At the time of lens removal, one-week into treatment with intravenous Penicillin G $\left(4 \times 10^{6}\right.$ units every
$4 \mathrm{~h})$ and $48 \mathrm{~h}$ post last dose of intraocular ampicillin $(5000 \mu \mathrm{g} / 0.1 \mathrm{ml})$, a sample of vitreous fluid was collected and stored at $-80^{\circ} \mathrm{C}$ until the time of analysis. Penicillin and Ampicillin levels were measured by a validated liquid chromatography with tandem mass spectrometry method. The vitreous sample was pretreated with Acetonitrile for protein precipitation, and penicillin, ampicillin and internal standard (6,7-Dimethyl-2,3-di (2pyridyl)-quinoxaline) were separated by high performance liquid chromatography with a C18 column. They were quantified by a triple quadruple mass spectrometer. Penicillin was linear between $0.06-5 \mu \mathrm{g} / \mathrm{ml}$ and ampicillin was linear between $0.12-2.5 \mu \mathrm{g} / \mathrm{ml}$.

\section{Results}

The intravitreal concentration of penicillin following 1 week of intravenous therapy, with associated clinical improvement, was $3.5 \mu \mathrm{g} / \mathrm{ml}$ (Table 1 ). With every fourhour dosing, this is at a time by which stable intraocular levels can be expected to have been achieved. The intravitreal concentration of ampicillin $48 \mathrm{~h}$ after the last administered intravitreal dose was $0.3 \mu \mathrm{g} / \mathrm{ml}$, marginally above the level of detection of the assay (Table 1).

\section{Discussion}

Penicillin has a broad spectrum of activity against Grampositive organisms and provides excellent activity against Streptococci and organisms commonly involved in bacterial endophthalmitis. However, data are lacking regarding the distribution of intravenous penicillin into the vitreous.

In two studies conducted in 1966 and 1967, the vitreal concentration of semi-synthetic penicillin derivatives oxacillin and methicillin were studied following systemic administration. In both cases, vitreal concentrations were below known therapeutic concentrations [6, 7]. A rabbit study evaluated the total concentration of penicillin in ocular tissues and found extremely high levels of penicillin in all ocular tissues except the lens and vitreous [8]. Similarly, inadequate levels of ampicillin were found in the vitreous of rabbit eyes following administration of intravenous ampicillin of $50 \mathrm{mg} / \mathrm{kg}$ [9]. In contrast, in 1998, Robinet et al. demonstrated the ability of piperacillin to adequately penetrate the vitreous cavity in humans, at concentrations sufficient to kill Grampositive organisms in inflamed eyes only [10].

Adequate therapeutic concentrations of antimicrobials are determined by the minimum inhibitory concentration (MIC) of an antimicrobial against a specific pathogen. In the case of postoperative endophthalmitis, $S$. pneumoniae and S. viridans are amongst the most common causative streptococci [11]. Typical MICs of penicillin against $S$. pneumoniae and $S$. viridans range from $0.25-1 \mu \mathrm{g} / \mathrm{ml}$ [12] and $0.125-4 \mu \mathrm{g} / \mathrm{ml}$ [13] respectively. 
Table 1 Intravitreal Penicillin and Ampicillin Concentrations

\begin{tabular}{lllll}
\hline Drug & Route & Dosing regimen & Intravitreal concentration & Range of quantitation \\
\hline Penicillin & Intravenous & 4 million $\cup$ q4h & $3.5 \mu \mathrm{g} / \mathrm{ml}^{\mathrm{a}}$ & $0.06-5 \mu \mathrm{g} / \mathrm{ml}$ \\
Ampicillin & Intravitreal & $5 \mathrm{mg}(5000 \mu \mathrm{g} / 0.1 \mathrm{ml})$ last administered $48 \mathrm{~h} \mathrm{prior}$ & $0.3 \mu \mathrm{g} /\left.\mathrm{ml}\right|^{\mathrm{a}}$ & $0.12-2.5 \mu \mathrm{g} / \mathrm{ml}$
\end{tabular}

a Levels were obtained from the same sample at the time of lens removal

Most importantly, the MIC of penicillin against most strains of Actinomyces ranges from $0.063-2 \mu \mathrm{g} / \mathrm{ml}$ [14]. As every four-hour dosing of intravenous penicillin would be expected to achieve constant levels of intravitreal penicillin, it reasonable to conclude that concentrations of penicillin achieved in the vitreous are sufficient for the treatment of common causes of post-operative endophthalmitis, including that caused by Actinomyces.

This study is the first to report adequate vitreal levels of penicillin against common endophthalmitis pathogens following intravenous administration. In this case, intravenously administered penicillin likely provided elevated intravitreal concentrations as a result of constant and continued diffusion from plasma. Anionic drugs including beta-lactams are subject to accelerated clearance via active transport across the BRB which, in this case, may have further promoted diffusion from the plasma into the vitreous cavity following the concentration gradient [15]. Our study found elevated levels of penicillin in the intravitreal space of an inflamed eye following intravenous administration, as seen with piperacillin [10]. This correlates well with studies that have found increased penetration of systemic antibiotics in inflamed eyes versus their non-inflamed counterparts [10, 15]. In inflamed eyes, drugs cleared by the posterior route, such as betalactams, demonstrate delayed clearance due to compromise of the RPE pump [15]. An extended half-life may have contributed to the elevated concentration of vitreal penicillin seen in our patient.

\section{Conclusion}

To successfully treat endophthalmitis, rapid administration of antibiotics to the posterior segment is necessary to prevent vision loss. In this report, we have shown that intravenous penicillin administered every $4 \mathrm{~h}$ allows for adequate concentrations in the vitreous. Future studies are required to determine if these favourable pharmacokinetics translate into improved clinical outcomes along with the potential benefit of limiting intraocular injections.

\section{Abbreviations}

EVS: Endophthalmitis Vitrectomy Study; BRB: Blood-retinal barrier; RPE: Retinal pigment epithelium; MIC: Minimum inhibitory concentration

\section{Authors' contributions}

All authors attest that they meet the current ICMJE criteria for authorship. All authors have read and approved the final manuscript.

\section{Authors' information}

$\mathrm{N} / \mathrm{a}$

\section{Funding}

No funding or grant support was received for this paper.

Availability of data and materials

All available results and data is provided in this report.

Ethics approval and consent to participate

Not required.

\section{Consent for publication}

Consent has been obtained by the patient involved in this report.

\section{Competing interests}

All authors declare that they have no competing interests.

\section{Author details}

${ }^{1}$ Faculty of Medicine, University of Ottawa, Ottawa, ON, Canada. ${ }^{2}$ Department of Ophthalmology, University of Ottawa, Ottawa, ON, Canada. ${ }^{3}$ Ottawa Hospital Research Institute, Ottawa, ON, Canada. ${ }^{4}$ Department of Medicine, Division on Infectious Diseases, University of Ottawa, Ottawa, ON, Canada.

Received: 23 August 2020 Accepted: 15 December 2020

Published online: 22 January 2021

References

1. Recchia F (2005) Changing trends in the microbiologic aspects of Postcataract Endophthalmitis. Arch Ophthalmol 123(3):341. https://doi.org/ 10.1001/archopht.123.3.341

2. Brockhaus L, Goldblum D, Eggenschwiler L, Zimmerli S, Marzolini C (2019) Revisiting systemic treatment of bacterial endophthalmitis: a review of intravitreal penetration of systemic antibiotics. Clin Microbiol Infect 25(11): 1364-1369. https://doi.org/10.1016/j.cmi.2019.01.017

3. Endophthalmitis Vitrectomy Study Group (1995) Results of the Endophthalmitis Vitrectomy study. Arch Ophthalmol 113(12):1479. https:// doi.org/10.1001/archopht.1995.01100120009001

4. Lopez-Cabezas C, Muner D, Massa M, Mensa PJ (2010) Antibiotics in Endophthalmitis: microbiological and pharmacokinetic considerations. Curr Clin Pharmacol 5(1):47-54. https://doi.org/10.2174/157488410790410597

5. Engelbert M, Miño de Kaspar $H$, Thiel M et al (2004) Intravitreal vancomycin and amikacin versus intravenous imipenem in the treatment of experimental Staphylococcus aureus endophthalmitis. Graefes Arch Clin Exp Ophthalmol 242(4):313-320. https://doi.org/10.1007/s00417-003-0767-9

6. Records R (1967) Human intraocular penetration of sodium Oxacillin. Arch Ophthalmol 77(5):693-695. https://doi.org/10.1001/archopht.1967. 00980020695026

7. Records R (1966) The human intraocular penetration of methicillin. Arch Ophthalmol 76(5):720-722. https://doi.org/10.1001/archopht.1966. 03850010722019

8. Bloome M (1970) Antibiotic concentration in ocular tissues. Arch Ophthalmol 83(1):78. https://doi.org/10.1001/archopht.1970.00990030080015

9. Salminen $L$ (1978) Ampicillin penetration into the rabbit eye. Acta Ophthalmol 56(6):977-983. https://doi.org/10.1111/j.1755-3768.1978. tb03817.x

10. Robinet A, Le Bot M, Colin J, Riche C (1998) Penetration of Piperacillin into the vitreous after intravenous administration. Retina. 18(6):526-530. https:// doi.org/10.1097/00006982-199806000-00006 
11. Yospaiboon Y, Meethongkam K, Sinawat S et al (2018) Predictive factors in the treatment of streptococcal endophthalmitis. Clin Ophthalmol 12:859864. https://doi.org/10.2147/opth.s161217

12. Clinical and Laboratory Standards Institute (2020) Performance Standards For Antimicrobial Susceptibility Testing, 30th edn. M100. Clinical and Laboratory Standards Institute, Wayne

13. Prabhu R, Piper K, Baddour L, Steckelberg J, Wilson W, Patel R (2004) Antimicrobial susceptibility patterns among Viridans group streptococcal isolates from infective endocarditis patients from 1971 to 1986 and 1994 to 2002. Antimicrob Agents Chemother 48(11):4463-4465. https://doi.org/10. 1128/aac.48.11.4463-4465.2004

14. Barberis C, Budia M, Palombarani S et al (2017) Antimicrobial susceptibility of clinical isolates of Actinomyces and related genera reveals an unusual clindamycin resistance among Actinomyces urogenitalis strains. J Glob Antimicrob Resist 8:115-120. https://doi.org/10.1016/.j.gar.2016.11.007

15. Radhika M, Mithal K, Bawdekar A et al (2014) Pharmacokinetics of intravitreal antibiotics in endophthalmitis. J Ophthalmic Inflamm Infect 4(1). https://doi. org/10.1186/s12348-014-0022-z

\section{Publisher's Note}

Springer Nature remains neutral with regard to jurisdictional claims in published maps and institutional affiliations.

\section{Submit your manuscript to a SpringerOpen ${ }^{\circ}$ journal and benefit from:}

- Convenient online submission

- Rigorous peer review

- Open access: articles freely available online

- High visibility within the field

Retaining the copyright to your article

Submit your next manuscript at $\boldsymbol{\nabla}$ springeropen.com 